Diabetologia 9, 203-209 (1973)

o by Springer-Verlag 1973

\title{
Lesions of Renal Glomeruli in Mice with Virus-Induced Diabetes Mellitus-Like Disease
}

\author{
R.E. Kanich, J.E. Craighead, and J.B. Kessler \\ Department of Pathology, University of Vermont College of Medicine, Burlington, Vermont 05401 , USA
}

Received: September 25, 1972 ; accepted: December 14, 1972

Summary. Encephalomyocarditis (EMC) virus infected DBA/2 mice develop a diabetes mellitus-like disease. Many animals survive the acute viral infection and exhibit hyperglycemia and glycosuria for varying periods thereafter. Accumulations of homogeneous, electron dense, basement membrane-like material are observed in the mesangium of the glomerulus of these animals as early as three months after inoculation. The peripheral capillary basement membranes are not affected. Since the alterations are not found in uninfected animals, it is assumed that the abnormal metabolic state or the virus infection, or both processes, are responsible for the glomerular changes. Further investigation will be required to elucidate the pathogenesis of this obscure lesion.

Key words: Encophalomyocarditis virus, Virus-induced diabetes, Diabetic ronal lesion.
A diabetes mellitus-like disease develops in mice infected with the " $M$ " variant of the encephalomyocarditis (EMC) virus. Its physiologic and pathologic features as well as the results of virologic studies on infected mice of the CD-1 Swiss strain have been described in previous publications from this laboratory $[2,4]$. Accordingly, only the salient features of the experimentally induced disease will be summarized here.

In brief, hyperglycemia and glycosuria appear in infected animals approximately four days after the inoculation of EMC virus. Low levels of plasma and pancreatic immunologically reactive insulin are found during the acute stages of the infection and large amounts of virus are recovered from the pancreas. The infection persists for about 10 days during which time approximately 15 to $30 \%$ of the animals die. A few survive for prolonged periods of time with hyperglycemia and glycosuria. Although the majority appear to recover and exhibit a seemingly normal metabolic state, many of these animals manifest abnormal glucose tolerance.

The pathogenesis of diabetic glomerulosclerosis in man is obscure. It is unclear whether the lesion is a direct effect of hyperglycemia or the consequent glycosuria, or is a manifestation of more subtle metabolic alterations. The present study was undertaken to determine if glomerular changes comparable to the human lesion develop in kidneys of mice with the chronic, virus-induced, diabetes mellitus-like disease. In this investigation DBA/2 mice were used inasmuch as the incidence of chronic diabetes developing in animals of this strain is relatively high after infection with the "M" varient of EMC.

\section{Material and Methods}

Twelve to 18 week-old, male DBA/2 mice (Microbiological Associates Inc., Walkersville, Maryland) were inoculated by the subcutaneous route with 10 to $100 \mathrm{PFU}$ of the "M" variant of EMC virus. Animals of a similar age and sex were inoculated with virus diluent and used as controls. All animals were housed in individual cages and offered water and Purina Lab Chow (protein $>23 \%$, Fat $>4.5 \%$, fiber $<6 \%$ ) ad libitum.

The amounts of glucose in the blood were determined by the glucose oxidase method [13] on specimens obtained from the retroorbital sinus before and three weeks after inoculation. Urine glucose was measured semiquantitatively at daily intervals during the acute stage of the infection and twice weekly thereafter using commerciallysupplied paper strips impregnated with glucose oxidase and a chromogen indicator (Labstix, Ames Co.). Details of our virological and biochemical techniques have been described in previous publications [2].

Twelve infected mice from four separate experiments were selected for morphological studies 2.5 to 4.5 months after virus inoculation. These animals were hyperglycemic three weeks after infection. Eleven of the 12 exhibited glycosuria over the total period of observation; the remaining animal was intermittently glycosuric. One or more uninfected animals from each experiment served as controls.

After light ether anesthesia and cervical disarticulation the kidneys were removed from infected and control animals and immersed in $4 \%$ glutaraldehyde, buffered with $0.1 \mathrm{M}$ cacodylate-HCl. They then were minced and fixed overnight. After rinsing in three changes of buffer, the tissues were post-fixed in 1 per cent osmium tetroxide in $0.1 \mathrm{M}$ cacodylate buffer, washed in saline, dehydrated in graded alcohols and propylene oxide, and embedded in Epon 812. One micron sections were stained with a mixture of $1 \%$ azure blue and $1 \%$ methylene blue or by the periodic acid-methenamine silver method [6]. Thin sections were studied in a Philips 300 electron microscopo after staining with uranyl acetate and lead citrate.

Basement membrane thickness was determined by obtaining the means of 70 measurements at random points along the peripheral glomerular capillaries, generally following the procedure described by Hansen [5].

Tissues also were fixed in phosphate buffered paraformaldehyde and embedded in paraffin. Five micron thick sections were stained with hematoxylin and eosin or the periodic acid-Schiff reagents.

\section{Results}

Table 1 summarizes pertinent data on the mice selected for this study. 
Electron microscopic examination of glomeruli from the 12 infected animals revealed accumulations of homogeneous electron dense material within the mesangia (Fig. 1). This intercellular material exhibited a fibrillar background and an electron density similar to the lamina densa of the basement membrane (Fig. 2). At several sites the deposits were in direct continuity with the basement membrane of the glomerulus. In these areas the lamina rarae internae of the basement membrane was obscured by the deposits. The lamina rarae externae was preserved and the foot processes of the epithelial cells did not extend to the laminae densa.

The amounts of amorphous material in the glomer- structure of both the endothelial and epithelial cells appeared normal. The peripheral glomerular basement membrane was not increased in thickness; its cross sectional width ranged from 75 to $200 \mathrm{~nm}$ in both infected and uninfected animals.

The morphologic features of the glomeruli of the C57 BL/KsJ and the spiny strains of mice have been recorded in recent publications $[9,11]$. Since the glomeruli of our uninfected DBA/2 animals appeared similar (Fig. 4), they will not be described further here. It is of interest, however, that two glomeruli in the kidneys of our control animals exhibited localized accumulations of matrix material (Table 1).

Table 1

\begin{tabular}{|c|c|c|c|c|c|c|c|c|c|c|c|}
\hline \multirow{3}{*}{\multicolumn{2}{|c|}{ Experiment }} & \multirow{3}{*}{$\begin{array}{l}\text { Virus } \\
\text { inoculated }\end{array}$} & \multicolumn{2}{|l|}{ Age at } & \multirow{2}{*}{\multicolumn{2}{|c|}{$\begin{array}{l}\text { Non-fasting } \\
\text { blood glucose } \\
(\mathrm{mg} / 100 \mathrm{ml})\end{array}$}} & \multirow{3}{*}{$\begin{array}{l}\text { Chronic } \\
\text { glycosuria }\end{array}$} & \multirow{2}{*}{\multicolumn{3}{|c|}{$\begin{array}{l}\text { Glomerular } \\
\text { mesangial lesions } \\
\text { (Number of } \\
\text { glomeruli) }\end{array}$}} & \multirow{3}{*}{$\begin{array}{l}\text { Number } \\
\text { glomeruli } \\
\text { examined }\end{array}$} \\
\hline & & & \multirow{2}{*}{$\begin{array}{l}\text { Inocula- } \\
\text { tion } \\
\text { (weeks) }\end{array}$} & \multirow[t]{2}{*}{$\begin{array}{l}\text { Sacrifice } \\
\text { (weeks) }\end{array}$} & & & & & & & \\
\hline & & & & & $\begin{array}{l}\text { Pre-infec- } \\
\text { tion }\end{array}$ & 21 days & & 0 & ++ & ++++ & \\
\hline A. & $\begin{array}{l}1 \\
2 \\
3\end{array}$ & $\begin{array}{l}\text { Yes } \\
\text { Yes } \\
\text { No }\end{array}$ & $\begin{array}{l}13 \\
13 \\
13\end{array}$ & $\begin{array}{l}24 \\
24 \\
24\end{array}$ & $\begin{array}{r}132 \\
108 \\
97\end{array}$ & $\begin{array}{l}393 \\
480 \\
125\end{array}$ & $\begin{array}{l}+^{a} \\
+ \\
0\end{array}$ & $\begin{array}{l}1^{c} \\
1 \\
4\end{array}$ & $\begin{array}{l}1 \\
3 \\
1\end{array}$ & $\begin{array}{l}3 \\
1 \\
0\end{array}$ & $\begin{array}{l}5 \\
5 \\
5\end{array}$ \\
\hline B & $\begin{array}{l}4 \\
5 \\
6\end{array}$ & $\begin{array}{l}\text { Yes } \\
\text { Yes } \\
\text { No }\end{array}$ & $\begin{array}{l}14 \\
14 \\
14\end{array}$ & $\begin{array}{l}27 \\
27 \\
27\end{array}$ & $\begin{array}{r}97 \\
97 \\
100\end{array}$ & $\begin{array}{l}435 \\
252 \\
117\end{array}$ & $\frac{+}{+}+$ & $\begin{array}{l}2 \\
3 \\
5\end{array}$ & $\begin{array}{l}2 \\
1 \\
0\end{array}$ & $\begin{array}{l}1 \\
1 \\
0\end{array}$ & $\begin{array}{l}5 \\
5 \\
5\end{array}$ \\
\hline $\mathrm{C}$ & $\begin{array}{r}7 \\
8 \\
9 \\
10 \\
11 \\
12\end{array}$ & $\begin{array}{l}\text { Yes } \\
\text { Yes } \\
\text { Yes } \\
\text { Yes } \\
\text { Yes } \\
\text { No }\end{array}$ & $\begin{array}{l}18 \\
18 \\
18 \\
18 \\
18 \\
18\end{array}$ & $\begin{array}{l}\mathbf{3 1} \\
\mathbf{3 1} \\
\mathbf{3 1} \\
\mathbf{3 1} \\
\mathbf{3 1} \\
\mathbf{3 1}\end{array}$ & $\begin{array}{r}88 \\
138 \\
145 \\
122 \\
175 \\
152\end{array}$ & $\begin{array}{l}355 \\
345 \\
330 \\
307 \\
400 \\
143\end{array}$ & $\begin{array}{l}+ \\
+ \\
+ \\
+ \\
+ \\
0\end{array}$ & $\begin{array}{l}3 \\
3 \\
3 \\
2 \\
1 \\
5\end{array}$ & $\begin{array}{l}1 \\
0 \\
1 \\
2 \\
2 \\
0\end{array}$ & $\begin{array}{l}1 \\
2 \\
1 \\
1 \\
2 \\
0\end{array}$ & $\begin{array}{l}5 \\
5 \\
5 \\
5 \\
5 \\
5\end{array}$ \\
\hline $\mathrm{D}$ & $\begin{array}{l}13 \\
14 \\
15 \\
16 \\
17\end{array}$ & $\begin{array}{l}\text { Yes } \\
\text { Yes } \\
\text { Yes } \\
\text { No } \\
\text { No }\end{array}$ & $\begin{array}{l}17 \\
17 \\
17 \\
17 \\
17\end{array}$ & $\begin{array}{l}34 \\
34 \\
34 \\
34 \\
34\end{array}$ & $\begin{array}{r}72 \\
93 \\
125 \\
130 \\
110\end{array}$ & $\begin{array}{l}340 \\
456 \\
176 \\
116 \\
132\end{array}$ & $\begin{array}{l}+ \\
+ \\
\pm^{+} \\
0 \\
0\end{array}$ & $\begin{array}{l}0 \\
1 \\
2 \\
4 \\
5\end{array}$ & $\begin{array}{l}0 \\
2 \\
1 \\
1 \\
0\end{array}$ & $\begin{array}{l}5 \\
2 \\
2 \\
0 \\
0\end{array}$ & $\begin{array}{l}5 \\
5 \\
5 \\
5 \\
5\end{array}$ \\
\hline
\end{tabular}

a - Glycosuria occurred from the fourth day after inoculation until the time of sacrifice.

b - Glycosuria occurred from the fourth day after inoculation to the seventh week, then at intervals thereafter.

c - Evaluation of the severity of the lesion was based upon the amounts of amorphous material deposited and extent of mesangial distortion:

$0=$ Material not increased or increased minimally.

$++=$ Material increased, but mesangial width normal.

$++++=$ Material markedly increased resulting in an increase in mesangial width.

uli of mice with glycosuria varied (Table 1 ). In some, the deposits were extensive, resulting in an increase in the width of the mesangium. The mesangial cells were somewhat obscured in these lesions. In other glomeruli the width of the mesangium was normal even though the amount of mesangial matrix was increased. The deposits reacted with the silver of the periodic acidmethenamine silver stain in a fashion similar to the basement membranes (Fig. 3), suggesting that it was comprised, at least in part, of glycoproteins. Uninvolved glomeruli occasionally were found in kidneys of diabetic animals (Table 1).

Cellular changes other than displacement of mesangial cells were not found within the glomeruli of mice with the virus-induced diabetes (Fig. 1). The

\section{Discussion}

The lesions in the renal glomeruli of mice with the chronic virus-induced diabetes mellitus-like disease characteristically consisted of intercellular deposits of amorphous electron-dense material in the mesangium. In many glomeruli the newly accumulated substance was sufficiently prominent to cause a marked thickening of the mesangium. Despite the presence of these alterations, basement membrane thickening of the glomerular capillaries was not evident. It is worthy of note that the animals included in this preliminary investigation were sacrificed only a few months after the onset of diabetes. Clearly, the natural history of the renal lesions will require detailed prospective study over the lifetime of these animals. 
It should be emphasized that the animals with the glomerular lesions sustained an acute, disseminated viral infection concomitant with the development of diabetes. It is unclear at present whether or not lesions could develop as a consequence of EMC virus infection of glomerular cells. Thus far, we have failed glomerular capillaries of adult mice during the acute stages of EMC infection [10]. Detailed virologic and immunologic studies of the renal glomeruli in mice infected with EMC virus are needed if we are to develop an understanding of the pathogenesis of the lesion described here.

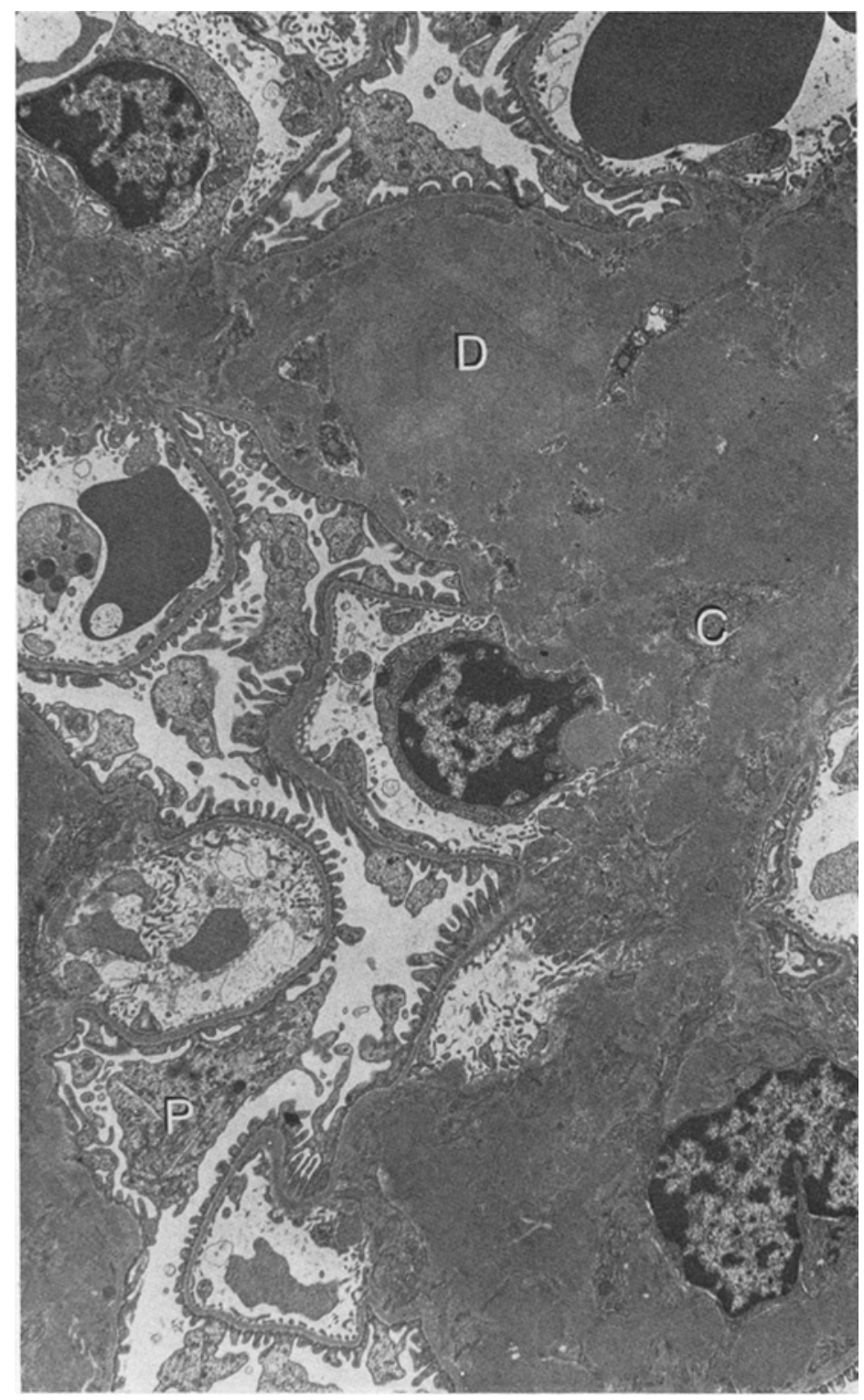

Fig. 1. Glomerulus of mouse with diabetes mellitus-like disease, sacrificed at 34 weeks of age. The mesangial width has increased due to the aceumulation of homogenous electron dense material (D) within the mesangium. Cytoplasmic Iragments (C) of the mesangial cell are scattered imregularly through the material. Endothelial (E) and epithelial (P) cell morphology is normal. Fusion of foot processes is not evident ( $\times 5600$ )

to demonstrate viral replication in the renal parenchyma and ultrastructural alterations have not been found in preliminary studies of the glomeruli in our acutely-infected animals [7]. On the other hand, Nakamura, using fluorescence microscopy, demonstrated the deposition of immune complexes in the
Previous investigators have shown that aging of the laboratory mouse is associated with thickening of the renal capillary basement membrane, changes in the number and size of mesangial cells, and the presence of increased amounts of matrix and collagen in the mesangium $[9,11]$. In these studies mice as old as 
36 months were examined [11]. The oldest mice included in this investigation were 8.5 months of age, a likely explanation for the infrequent presence of the glomeruli, was excluded by the ultrastructural appearance of the material and the lack of birefringence with the alkaline congo red stain [3].

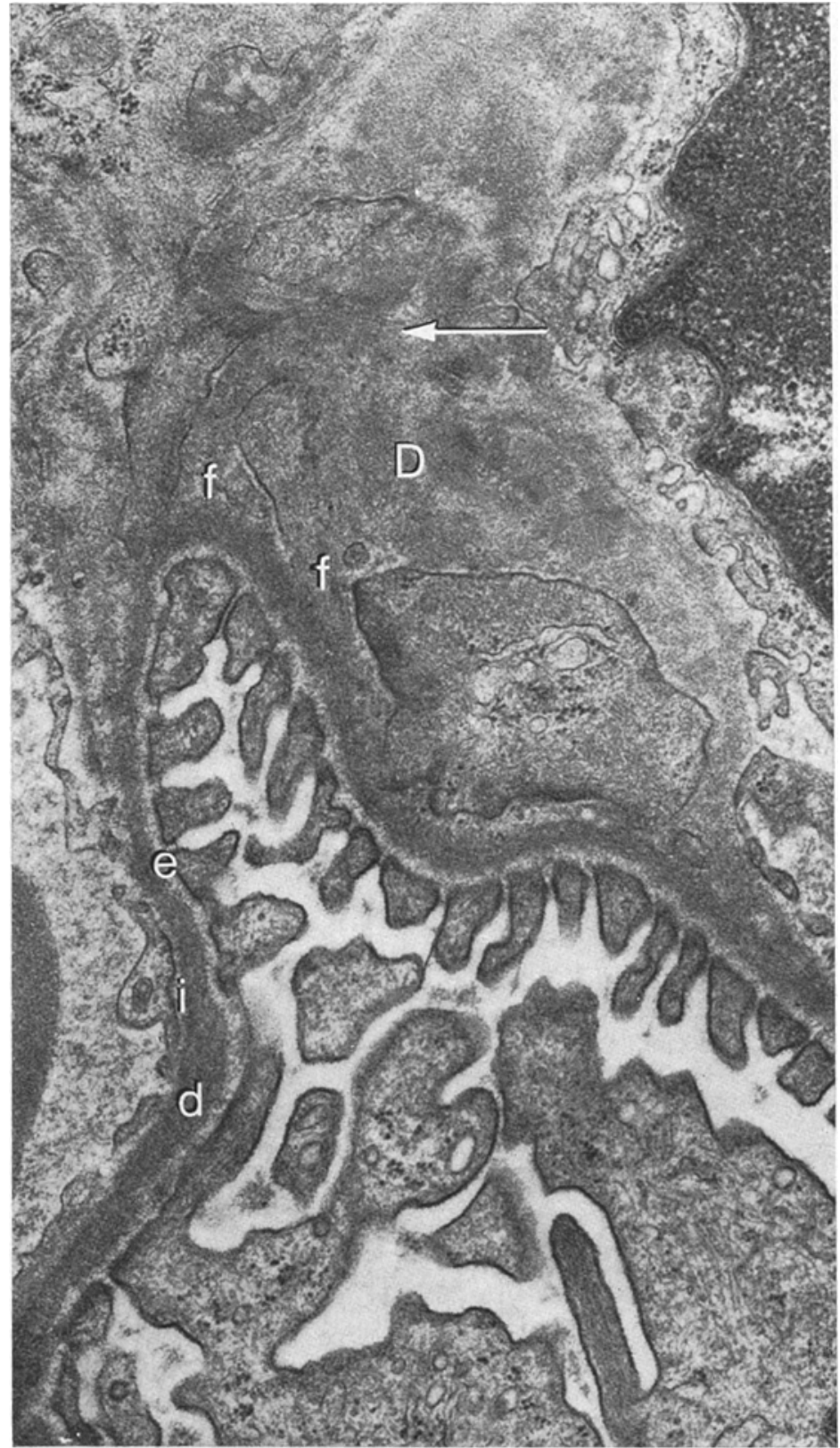

Fig. 2. Glomerulus of mouse with diabetes mellitus-like disease, sacrificed at 34 woeks of age. At scattered sites the mesangial deposits are continuous with the basement membrane. The deposits (D) have an electron density similar to the lamina densa (d) of the basement membrane, but a fibrillar texture is evident at several foci (arrow). At the site of apparent fusion, the lamina rarae interna is indistinct $(\mathbf{F})$. In other areas, particularly the peripheral basement membrane, the lamina rarae interna (i) is evident. The lamina rarae externa (e) has been preserved throughout and the foot processes are embedded within it $(\times 28000)$

alterations attributable to aging in the kidneys of uninfected control animals. Renal amyloidosis, another process characterized by homogeneous deposits within
Glomerular lesions similar to those described here have been reported in dogs treated with alloxan [1], and in Chinese hamsters with naturally-occurring diabetes 
mellitus [12]. The renal lesions in the $\mathrm{C} 57 \mathrm{BL} / \mathrm{K}_{\mathrm{s}-\mathrm{db} / \mathrm{db}}$ [9] and the diabetic spiny mice [11] are of particular interest. They consist of a diffuse, although minimal, in non-diabetic mice, it has been suggested that metabolic alterations associated with the diabetic state accelerate the aging process within the glomeruli [9].

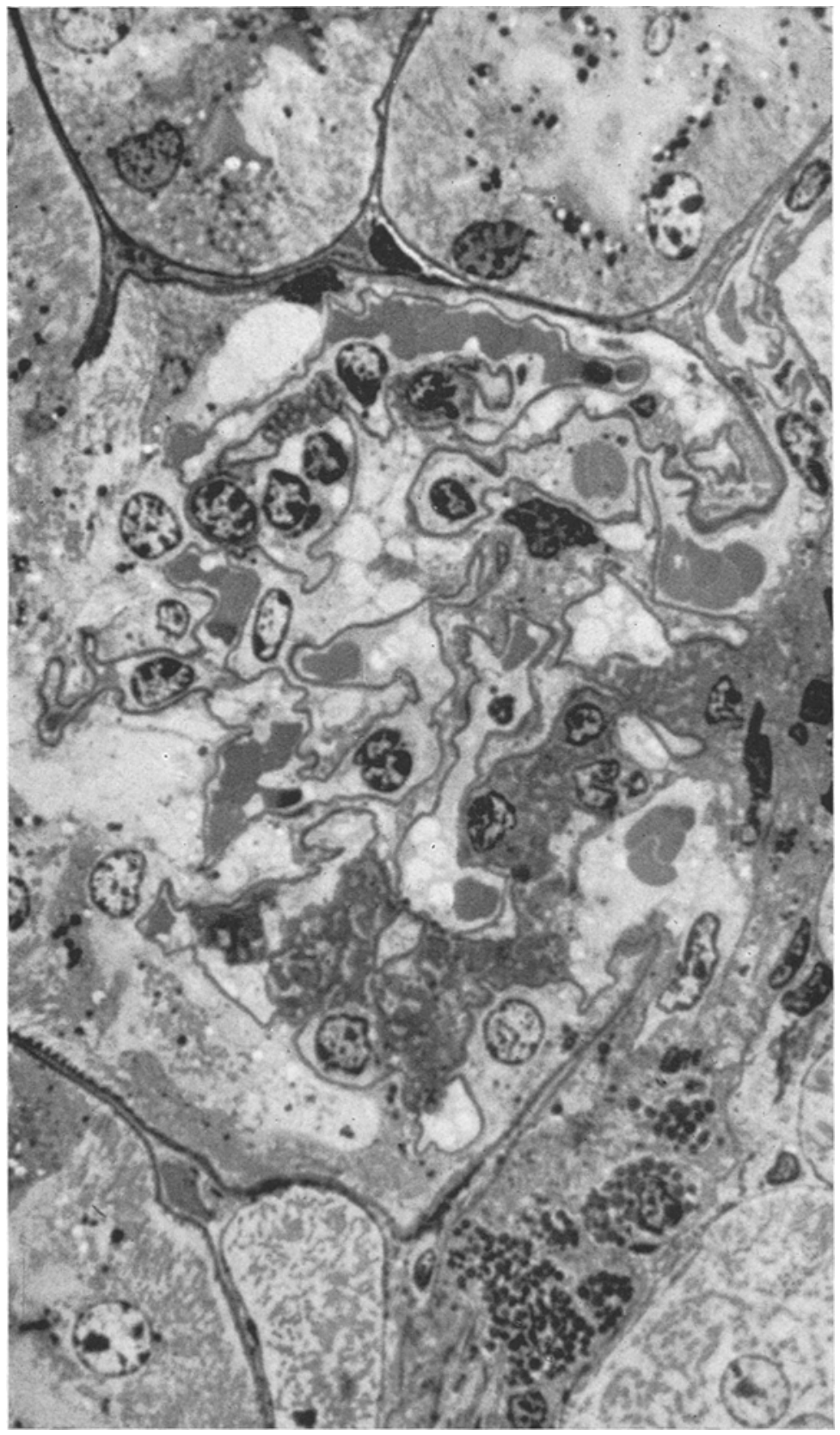

Fig. 3. Glomerulus of mouse with the diabetes-like disease, sacrificed 31 weeks of age. The mesangial deposits in the glomeruli react with the silver of the periodic acidmethenamine silver in a manner similar to the basement membrane. Paraformaldehyde fixation $(\times 960)$

thickening of the basement membrane as well as an increase in the amount of mesangial matrix and collagen. Since these alterations are similar to the aging changes
By light microscopy the early glomerular lesion in patients with diabetes mellitus consist of deposits of hyaline-like material, either within the mesangium, or 
at more peripheral locations in the glomerulus [8]. This lesion is found in glomeruli that do not exhibit an increase in peripheral basement membrane thickness.
Acknowledgements. This research was supported by U.S. Public Health Service Grant AI 09118 from the National Institute of Allergy and Infectious Diseases.

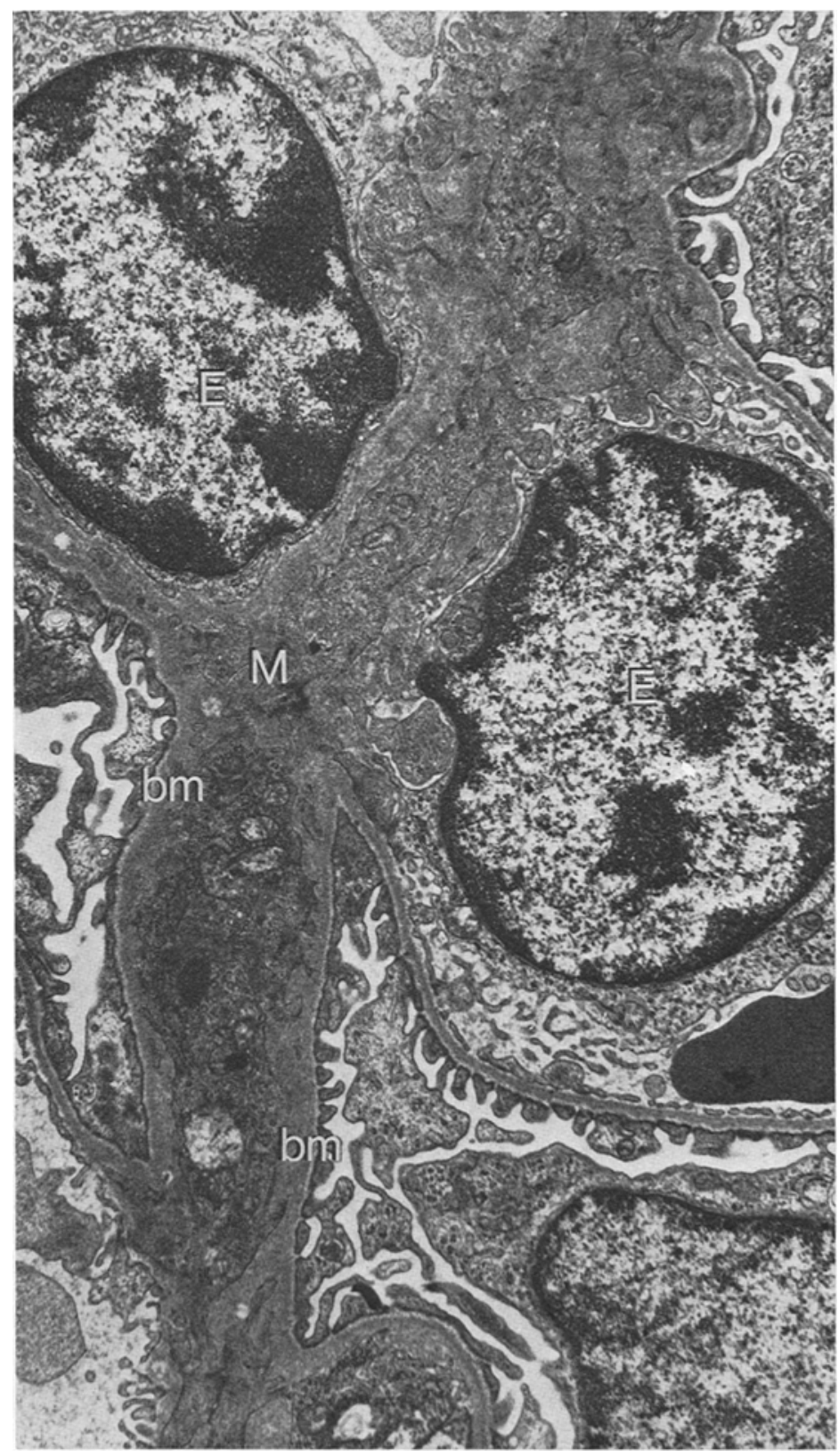

Fig. 4. Glomerulus of uninfected mouse, sacrificed at 34 weeks of age. The mesangium is enclosed by the basement membrane $(\mathrm{bm})$ or capillary endothelial cells $(\mathrm{E})$. The amount of mesangial matrix $(\mathrm{M})$ varied somewhat $(X 14280)$

These alterations closely resemble the changes we found in the kidneys of our mice. Inasmuch as renal disease is a serious complication of diabetes mellitus and its pathogenesis and relationship to current modes of therapy is unclear, we feel that the glomerular disease in mice with virus-induced diabetes is a sound model upon which to base further investigations.

\section{References}

1. Bloodworth, J.M.B.: Experimental diabetic glomerulosclerosis. II. The dog. Arch. Path. 79, 113-134 (1965).

2. Craighead, J.E., Steinke, J.: Diabetes mellitus-like syndrome in mice infected with EMC virus. Amer. J. Path. 63, 119-130 (1971). 
3. Cohen, A.S.: Constitution and genesis of amyloid, in International Review of Experimental Pathology, Vol. IV, (Eds. Richter, G. W., Epstein, M. S.), p. 159. New York: Academic Press, Inc., Publishers 1965.

4. From, G.L.A., Craighead, J.E., MeLain, M.F., Steinke, J.: Virus induced diabetes in mice. Metabolism 17, 1154-1158 (1968).

5. Hansen, R.O.: A Quantitative estimate of the peripheral glomerular basement membrane in acute juvenile diabetes. Diabetologia 1, 97-100 (1965).

6. Jones, D.B.: Nephrotic glomerulonephritis. Amer. J. Path. 33, 313-329 (1957).

7. Kanich, R.E., Craighead, J.E.: Unpublished results.

8. Kimmelstiel, P., Kim, O.J., Beres, J.: Studies on renal biopsy specimens with the aid of the electron microscope. I. Glomeruli in diabetes. Amer. J. clin. Path. 38, 270-279 (1962).

9. Like, A.A., Lavine, R.L., Poffenbarger, P.L., Chick, W.L.: Studies in the diabetic mutant mouse. VT. Evolution of glomerular lesions and associated proteinuria. Amer. J. Path. 66, 193 (1972).
10. Nakamura, R.M.: Unpublished results.

11. Orci, L., Stauffacher, W., Amherdt, M., Pictet, R., Renold, A. E., Rouillen, Ch.: The kidney of spiny mice (Acomys Cahirinus) : electron microscopy of glomerular changes associated with aging and tubular glycogen accumulation during hyperglycemia. Diabetologia $6,343-355(1970)$.

12. Shirai, T., Welsh, G.W., III, Sims, E.A.H.: Diabetes mellitus in the Chinese hamster. II. The evolution of renal glomerulopathy. Diabetologia 3, 266-286 (1967).

13. Washdo, M.E., Rice, E.W.: Determination of glucose by an improved enzymatic procedure. Clin. Chem. 7, $542-545(1961)$.

R.E. Kanich, M.D.

University of Vermont

Dept. of Pathology and Oncology

Medical Alumni Building

Burlington, Vermont 05401

U.S.A. 